\title{
Islamic Managers And The Role Of Emotional Maturity In Decision-Making (Review of al-Qur'an and science)
}

\author{
Iwan Fahri Cahyadi' ${ }^{1}$ Zulham Fanani ${ }^{2}$ \\ Institut Agama Islam Negeri Kudus ${ }^{12}$ \\ iwanfahri@iainkudus.ac.id¹, M.yulhamfanani@gmail.com²
}

\begin{abstract}
The role of managers in a company has a very strategic position, be it a large, medium or small scale company, although in each company the problems faced have different complexity and risk. This is where managers must be able to analyze problems or problems, choose and sort out various alternatives in solving a problem, take the best decisions and have the lowest risk, and be able to analyze the potential problems that arise in the future. A manager is required not only to have extensive knowledge and insight, but also emotional maturity. Like two sides of a coin, these two things must be utilized simultaneously in decision making so that the right decision is taken. Science and insights are physiological (brain) obtained from schools and their environments. While emotional maturity through religious approaches. Managers who practice religion well (Islamic Managers) then the maturity of their souls is more stable and secure. The manager who is close to God will get the happiness that comes from the endhorpin hormone that is present in humans that has been provided by God. Keywords : Manager, Leader, Endhorpin, Problem Solving, Decision Making
\end{abstract}

\section{INTRODUCTION}

The role of managers in a company has a very strategic position, be it a large, medium, or small scale company, even though at each scale, the problems faced have different risks. The greater a business, the complexity of the problems faced are increasingly varied and complicated such as human resources, operations, finance, marketing, and so forth. Therefore, sustainability. The future life of a company is determined by managers in managing the company, solving problems encountered, and making the right decisions.

According to Widyarini (2012: 135), the nature in question is that person includes a Risk Lover (people who like high risk), Risk Takers (people who like medium risk), or Risk Averter (people who like low risk). Each of the characteristics possessed by these decision-makers usually also reflects the line of business that is cultivated by managers. According to Fazio (2019: 295-296), in decision making, a manager may face three conditions, namely certainty: risk and uncertainty. The ideal situation is a situation that is full of certainty. This means that the situation allows managers to make decisions because the results of each alternative are known. Risk is a result that may arise because of a decision. A manager must choose an alternative risk that must be faced as a consequence of his decision-alternatives related to risk, usually owned by managers based on experience and information from other parties. Uncertainty is a condition where managers do not have much 
information that can be used as a basis for decision making. Another factor influencing choices in uncertain circumstances is a psychological orientation or emotional maturity in decision making. In uncertain conditions, decision making is based on the nature of the decision-maker, from several results of research on the role of managers in decision making as written by Mulyadi (2003), that the style adopted by a manager (leader) is very decisive for the right decision. Therefore a manager must master decision-making techniques so that they have good quality in solving a problem in an organization or company.

Another study was written by Sola (2018) entitled "Decision Making: A Preliminary Study" discusses the process of identifying problems and stages of decision making based on accuracy, accuracy, and rationality (intellectual quotient) so those decision-makers, in this case, leaders, must be careful see whether the problem is classified as a type of problem that is general and routinely experienced, or problems that are specific, specific and rarely occur. An understanding of the existence of problems will help leaders in developing various alternative solutions. In the next process, the alternatives that have been developed are evaluated by setting various criteria for each alternative by taking into account the strengths and weaknesses of each. From the results of evaluating various alternatives, the next process is to choose the best alternative to make the decision to be implemented. For some decisions, it is necessary to monitor the implementation of decisions to see the effectiveness of those decisions. Judgment, intuition, and creativity of the organization's leaders are the primary keys to making the right and practical decision.

The two research journals above still discuss decision-making techniques in an intellectual quotient (IQ) perspective and are standardized, without involving the emotional quotient (EQ) or emotional maturity. The gap research journal that this researcher will describe compared to the two research journals above is (1) How in decision making involves emotional maturity so that in deciding a problem better and (2) How is the role of religion in decision making so that decisions are made wiser. While the purpose of writing this journal is (1), providing concepts, ideas, and ideas in decision making involving emotional maturity (2). How does the role of religion affect the emotional maturity of a manager or leader in decision making?

\section{LITERATUR REVIEW}

Many opinions about understanding. Decision making is essentially a systematic approach to a matter of gathering facts and data, determining alternatives, and taking the most appropriate action based on the situation. For managers who rely more on rationality (IQ), four stages must be passed (Kepner and Tragoe, 1992: 9-10).

A leader must be good at managing to be realized by teaching people to use consciously and together with four fundamental patterns of thinking to 
solve a problem that they have used unconsciously and individually. The four fundamental patterns of thinking are described in four kinds of questions that are asked every day by a manager, namely (1) what happens? (2) Why did this happen? (3) What actions should we take? (4). What happens to what we face?

What happened? This question requires an explanation. This question requires a description, breakdown, research of all new events, how to achieve and maintain control. That question illustrates the mindset that allows us to bring order to all that is chaotic and uncertain. That question allows us to set priorities and decide when and how to take actions that are useful and produce good results. Why did that happen? This question requires us to think based on cause and effect. It second basic pattern of thinking. This pattern allows us to move from observing the effects of problems to understanding why. Thus we can take appropriate action to correct the problem or reduce the consequences.

What action should we take? This question implies that we must make a choice. This third basic pattern of thinking allows us to decide which actions are most likely to achieve specific goals. What we are facing this question examines our future using this fourth essential mindset if we try to assess the problems that might occur decisions that may be needed next month or five years.

According to Kepner and Tragoe (1992: 14-16), for a manager or leader who relies on rationality, four stages must be passed to solve a problem. The first is a situation assessment which is how we assess and explain the situation detailing a complicated situation into manageable parts and maintaining control of an event. If a management situation occurs, the information available is generally still a complicated mixture of relevant and irrelevant matters, which are essential and inconsistent, before we can do something that makes sense or is productive. A complicated situation must be sorted so that its parts can be seen in terms of the fact that we must set priorities and must delegate actions we must have the tools to monitor information when the old situation has been resolved, and a new situation arises. Situation assessments are designed to recognize the problems that must be resolved; decisions must be taken, and future events must be analyzed and planned. Therefore we must understand the rationale processes that can be applied in these fields before learning the techniques and procedure processes.

The second ration, called problem analysis based on the cause and effect thinking patterns, allows us to carefully recognize, describe, analyze, and solve situations where something goes wrong without any explanation. This process gives us a method for extracting meaningful information about a difficult situation and gets rid of information that is a less relevant process.

The third rationale that is based on the mindset of making choices is called decision analysis using this process. We can look the situation first before making decisions and evaluate the three parts. We can analyze the 
reasons for decision making and examine the objectives. We can analyze the options available to achieve the objectives that we can analyze the relative risks of each alternative. From a clear picture of this situation, we can then make the wisest and safest choice a choice made after careful consideration of all factors.

The fourth rational process is based on our concern about future events regarding events that may occur and can occur. We call this process the analysis of potential problems. Potential problems will occur if we can predict difficulties that may arise in certain situations. No one knows for sure that difficulties will arise, but no one can guarantee that difficulties will not occur. This process uses what we know or can safely assume to get rid of the negative consequences that may arise in the future. The process is based on the idea that it is thinking and acting beforehand to prevent problems from arising is more efficient than solving an issue that is allowed to develop. This rational process allows the organization to act actively to determine its future (Kepner and Tragoe, 1992).

A decision making distinguishes the decisions that have been programmed and those that are not programmed. Decisions are programmed if carried out for routine or repetitive activities and have developed specific procedures to overcome them. Programmed decisions have generally been handled based on norms of work procedures and organizational structures that have developed specific procedures for handling them, while decisions that are not programmed are new and are not well structured because they are specific. Cases that require these decisions have not been experienced before decisions that are not programmed must be identified precisely because the impact can be related to the need for large amounts of funds. Decisions that are not programmed generally involve top management while middle managers and line managers mostly do programable decision making because both managers say they handle more operational activities within the company (Mc. Lead and Schell, 2008).

Decision making is a management process that is very important for every manager. Decision making means a process of assessment and selection of several alternatives by specific interests by determining the choices that are considered most beneficial in the decision making the process of a leader (both individually and in groups) must be rational (objective and logical) prioritizing organizational interests and sensitivity (intuition ) to get the best decision. Using intuition does not mean having to leave rationality, but the two complement each other. Intuition itself is formed due to several influences including experience, ethical or cultural values, unconscious mental processing or cognitive decisions, and emotional maturity.

From the above explanation, it can be concluded that decision making by managers or leaders must not only rely on rationality but also emotional maturity. Like two sides of a coin, they must become a unified whole. What happens if the decision is based on haste, and in a condition of anger, then the 
decision taken is certainly not right. It is where the role of religion is vital because religion will form emotional maturity, patience, and a calm soul. Thus, the decision taken will be better.

\section{RESEARCH METHOD}

The research method uses qualitative research methods that are based on the philosophy of postpositivism that views social reality as a holistic or intact, complex, dynamic, full of meaning, and the relationship of symptoms is interactive (Narbuko, et al., 2002). The research method using secondary data later from that data was interpreted by the researchers subjectively. The qualitative method is descriptive, the data collected in the form of words or images, not only emphasizing numbers (Sugiono, 2008: 9). The approach used is phenomenology, a qualitative methodology that allows researchers to apply and apply their personal and interpersonal abilities in the exploratory process (Alase, 2017: 9). The data source is obtained from secondary data, namely data sources that do not directly provide data to data collectors, for example, documents, journals, research results, and books (Basrowi, 2008: 158).

\section{RESULTS AND DISCUSSION}

In Islam, several terms refer to the understanding of the first leader of the word Umaroh which is often referred to as Ulul Amri. is said in the Qur'an in the An-Nisaa letter: 59), "You who believe, obey Allah and obey the apostles and It ulil amri among you. Then if have different opinions about something, return it to Allah (the Quran) and his apostle (his Sunnah). If you truly believe in Allah and the day after that is more important to you and better the consequences ". (QS. An-Nisaa: 59).

According to Shihab, (2000: 459), after God commanded the leaders and those in the office to be just towards their people, then God commanded the people to obey their leaders; He said, Obey Allah and obey him, and obey the Messenger of Allah, and obey everyone who governs the affairs of the Muslims. If you disagree with the leader of the work in a religious matter, then go back to the Qur'an and the Sunnah, for this is the basis of faith and contains a better end for you in this world and the Hereafter.

Second, the leader is often called Khadimul Ummah (servant of the people) according to that term; a leader must put himself in the position of being a public servant (servant of the company). A company leader must try to think of ways for the company he leads to prospering, prosperous employees, and the community or the environment to enjoy the company's presence. For leaders who are serving, the power they lead is not merely formalistic because of their position, but a power that gives birth to a power that is born from consciousness. An example, in this case, is Abdurrahman bin Auf, a businessman in the time of the Prophet Muhammad.

Sheikh Muhammad Al Mubarok stated that there were four conditions for a person to become a leader: 
1. Have the correct aqeedah.

2. Have broad knowledge and insight. Third, have a noble character.

3. Have managerial skills, understand the science of administration, and management in managing worldly affairs.

These are the conditions that must be used as a benchmark by Muslims in choosing a leader. From the four benchmarks, it can be seen that the first and third conditions relate to religion, so the role of religion is vital for a leader. The Qur'an al-Maidah: 57 confirms that Muslims who genuinely believe in Allah and believe in the Prophet Sallallahu Alaihi Wa salam are strictly forbidden to choose a leader who has no concern with religious matters or someone who makes religion as a game material because the responsibility for appointing a leader will be returned to those who appoint him. So the problem of leadership is not only related to the person who was appointed as a leader but also related to the faith of the people who raised it. At the end of the verse, surah al-Maidah: 57 Allah affirms, ".... and fear you if Allah is truly a believer." (QS. Al-Maidah: 57).

In Islamic literature or history, there is an event during the Khandaq war. Fewer Muslims have to deal with the Quraish coalition. An unbalanced amount. The Prophet as a prophet and the leader of the people, asked Allah SWT for help and as a form of his brother discussed with his companions to solve the problem. After discussions, he approved Salman al-Pharisee's proposal to create a trench (Khandaq) around the city of Medina to withstand attacks by Quraish coalition forces. The Prophet went down directly and worked to make a trench with his companions. His example as a leader shows that in human resources management, leaders must be objective, able to provide examples and examples, and egalitarian (Siswanto, 2020: 108)

For a manager or leader in managing a company cannot be separated from a problem or problem. How does the Islamic religion provide tips for a leader to be able to think in dealing with various problems so that he can think clearly and productively, which will ultimately produce innovative and useful works? There are at least two things that a leader needs to do. First, always try as much as possible to get closer to Allah SWT by carrying out all His provisions and stay away from everything that is forbidden by Him. Prayers and prayers are always echoed so that Allah SWT always provides guidance and assistance in every activity undertaken. Second, all the first leaders of leaders who hold this mandate to see and appreciate the various problems faced by members of the organization will encourage the sensitivity of the heart and the sharpness of thought to solve various problems that exist comprehensively and visionary by utilizing all the potential they have.

The peace of mind or emotional quotient of a leader is needed in solving a problem and making the right decision for the company. An Islamic man (leader) then Allah gives his instructions in the Qur'an surah ar-Ra'd: 28 so that leaders have a calm heart, "believers and their hearts are at peace with 
the remembrance of Allah. Remember only by remembrance of Allah, hearts become serene".

For an Islamic leader who should realize that humans are not able to solve the problems faced without the help of Allah SWT. Therefore, all activities carried out must always involve Allah SWT, including in facing company problems and in making good decisions. The process of worship that is right and is accompanied by pray will make a leader mentally well and controlled. Emotional maturity is more awake and the soul becomes calm.

In the era of the industrial revolution 4.0, the highest criteria for a leader is maturity. From the side of psychology, maturity is characterized by objective thinking, positive thinking, being able to control and channel emotions, being responsible, and being able to foster harmonious and consistent interpersonal relationships in a relatively long period. The immaturity of a manager or leader is usually seen in the courage of the leader to make decisions, impose opinions, and abuse power, and the inability to foster human relations legally and responsibly. From this fact, we can learn that primary education and intelligence do not always correlate with personal maturity, mainly if the individual develops the functions within himself in a one-sided manner. For example, he thinks a lot without developing personality in everyday life in organizations. From this fact that maturity is not inherited, it is not innate from birth but is learned and trained. Besides, that maturity or immaturity can also be eroded and transmitted if we are in an organization whose environment is not right, then maturity will gradually erode (Rachman, 2017). Therefore, for an Islamic leader who is always close to Allah so that the maturity of his soul is always guarded through worship and pray to Allah SWT

The calmness of one's soul is identical to self-actualization if we refer to Maslow's theory of basic human needs, so today is very relevant. Based on this theory, Maslow divides these overall needs into five categories. This category of needs is indeed like a pyramid; we move from one low level to a higher level. In this pyramid, the basic human needs, namely the physical, are in the first and lowest position. In the first place, there are breathing activities, drinking food, sleeping, and inner needs (sex) which usually appear as instincts of encouragement or ambition. These needs must be satisfied to survive. The origin of this impulse is the reptile brain. When these basic physical needs are met, next comes a demand for security. When our stomachs are empty, we look for something that can be eaten without regard to shame or shameful deeds and instead do not care about the danger, but once the goal is reached we gradually begin to think about self-safety. The third type of first and second types of needs have been satisfied the next level is the social relations of this stage involves the need for individuals to live as members of a group that can be described as demands for community life. Love falls into this category because love requires objects and is based on social relationships. Now that three empty stomach needs have been fulfilled, security has been established, and as members of our society, we have been 
accepted as group members. However, according to Maslow, human beings who have reached all three levels of initial need are not yet satisfied.

Further needs are social recognition and self-actualization. This need is about the recognition from others which is also related to self-esteem, including, among others, self-confidence that is greater than others, a strong belief in one's abilities, tangible results of self-performance, and affirmation of independence behind the stored desire to make yourself proud of these things and the hope that this achievement is recognized by others proof of recognition such as titles, fame and nicknames are the embodiment of this desire. However, man is not satisfied with this form of social recognition, besides he also wants to realize the hope of getting an award truly from other people.

When a human has reached this point, he has advanced somewhat even though he has not reached his destination. This is where the fifth and final need is self-actualization in the role of humans who have reached the 4th level, as Maslow said, "desiring to take full advantage of opportunities to reach the highest level of existence". Maslow called this the need for selfactualization or transcendence of a mental state that guides to the realm of divinity.

There are various theories of HR management (leadership) resulting from various experiences and experiments. Some HR managers are trying their hardest to find a management model with various theories developing in the Eastern and Western hemispheres, such as Chinese, Japanese, and "Western" models. Allah Almighty, all human beings (scientists) who want to think and use their minds will get teaching from Allah SWT. According to Siswanto (2020: 10-11), for a Muslim, the law is valid if you want to practice the theory. However, it would be nice if a Muslim also examples what the Prophet Muhammad has practised. Islam is a comprehensive and universal religion that talks about the life of the world and the Hereafter.

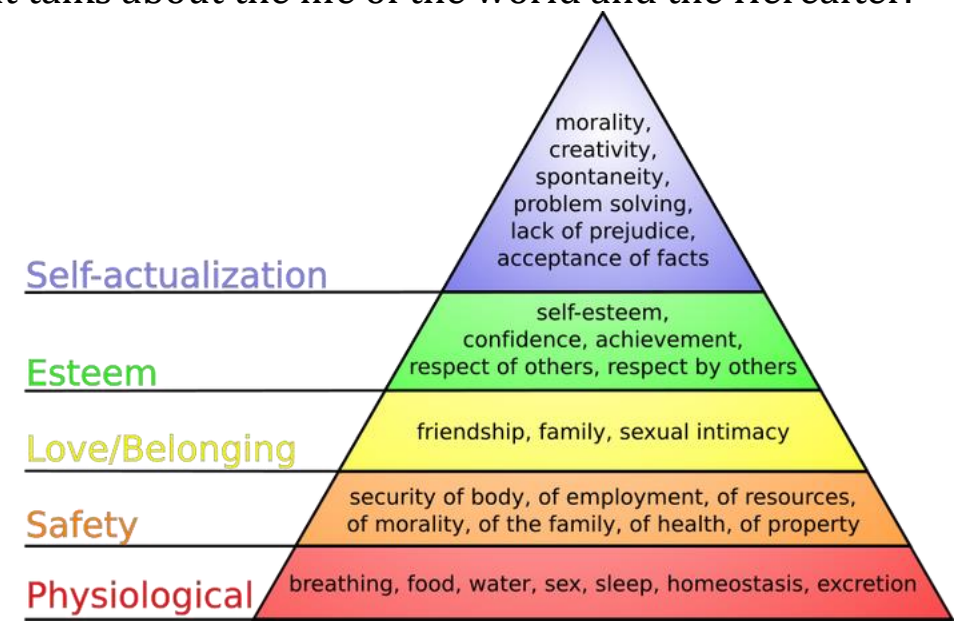

Maslow compiled his famous theory more than 50 years ago. Here we had just proven and learned that brain function and the theory of needs corresponded when Maslow developed his theory of brain function. Based 
on the current level of knowledge aMaslow's theory is considered to be truly qualified to understand basic human needs in terms of brain physiology.

If this knowledge would indeed be applied to normal humans, we would not have to wait until everything reached the 5 th level of need. Not many people achieve the goal of self-actualization (transcendent or divinity) while almost all make it to the third level, namely the need for groups and love. $t$ thBut most people survive at this level or at the next level that is fighting for recognition. What important thing does hormone happiness or endorphins teach us about brain function? Implicitly this hormone requires humans to reach the fifth level and strive to achieve the goal of self-actualization of those who want to use their brains intelligently and thoroughly (Harunaya, 1995)

In humans, there are several types of hormones, one of which is the endorphin hormone or happiness. This type of hormone will appear when humans are in a transcendent position or close to God through worship and prayer to Allah SWT beliefs that make the brain and heart calm. This is what is needed by an Islamic leader in dealing with company problems and as a contribution to making the right decision.

In essence, between science and the contents of the Qur'an, there is no contradiction, as well as the hormones in the human body, are also explained in the Qur'an. As we know, there are several types of hormones in the human body. The first is the hormone endorphins generating an atmosphere of happiness or in the language of religion sakinah mawadah wa rohmah. For people who pray to God then the endorphins will rise in the human body so that it produces a feeling of happiness, gratitude, pleasure, happiness, and finally willingness to accept and live the situation sincerely. The power of sincerity accepts and lives life with the emergence of the hormone endorphin stronger than 300 times morphine. Clearly, Allah explained in the Surah alFath verse 4, "He (Allah) who decreases calm into the hearts of those who believe to increase their existing faith".

Second, the hormone serotonin is a generator of human creativity. Creative nature cannot be created by someone with the provision of knowledge alone because creativity is a gift from God or His instructions. Creative people are the best people who are created for humans because they can find something useful for many people. Ali Imran 110. As we all know, humans are blessed with 3 bits of intelligence, namely intellectual quotient (IQ), emotional quotient (EQ), and spiritual quotient (SQ). These three bits of intelligence are contained in Fathir verse 32, "Then We left the book to those whom we chose among our servants, then there were those who persecuted themselves and among them were intermediaries and among them, there are (also) those who first did well with the permission of Allah. That is a tremendous gift".

Third, the hormone dopamine is a spirit of worship (including work). Humans on earth as a caliph have a duty to worship, this is by the letter AdzDzariyat verse 56, "And I did not create jinn and humans and send the 
apostles except for noble purposes, namely worship only to be alone not to other than me."

So that humans on earth can generate dopamine in themselves, they learn to justify what they do and without blaming other people who are different. Fourth, the hormone oxytocin is the generator of human affection how this hormone can rise; we must understand the meaning of difference is God's gift. Fifth, the hormone melatonin is a human immune generator how the hormone melatonin continues to function to maintain the health of the human body and soul since it was created until its death. Sixth, the hormone cortisol, which generates a lot of complaining atmospheres, will give birth to stress disease and will eat bones or osteoporosis.

Therefore, whoever can generate endorphins; his life will be filled with happiness and calmness. When the endorphin hormone functions, the cortisol hormone is defeated, while the other four hormones will carry out their respective duties to nourish the body and soul. From the description above, it becomes clear that Islamic leaders should have more peace than those who live far from religion or do not carry out God's commands. Peace of mind is the inner capital that must be collaborated with knowledge or insight (physiology) that must be owned by a manager or leader in dealing with every problem in his company so that decisions are better and more appropriate.

\section{CONCLUSION}

From the description of the theory, referendum, literature, journal, and book, it can be concluded: 1) That every company always faces problems both structured, semi-structured, and unstructured. This problem must be solved immediately through decision making. 2) Decision-making steps through several stages, namely problem analysis, choosing several alternative problem solving, decision analysis, and analysis of potential problems. 3) A leader in the company has a very strategic role. A leader is not only smart in science (physiological or brain) but also has a mental or inner maturity in making a decision. Both are like two sides of a coin that must be used together in decision making so that the results obtained are exact.

\section{REFERENCES}

Alase, Abayomi, The Interpretative Phenomenological Analysis (IPA): A Guide to a Good Qualitative Research Approach, International Journal of Education and Literacy Studies, Vol. 5 No. 2, April 2017, DOI: 10.7575/aiac.ijels. v.5n.2p.9.

Basrowi, Suwandi, (2008), Memahami Penelitian Kualitatif, Rineka Cipta, Jakarta, p. 158.

Fauzia, Ika Yunia, (2019), Islamic Entrepreneurship, Rajawali Press, Depok, pages 295-296

Hafidhuddin dan Tanjung, (2005), Manajemen Syariah dalam Praktik, Gema Insani, Jakarta. 
Islamic Managers And The Role Of Emotional Maturity In Decision-Making (Review of al-Qur'an and science)

Harunaya, Shigeo, (1995), The Miracle of Endhorpin: Sehat Mudah dan Praktis dengan Hormon Kebahagiaan, PT. Mizan Pustaka Ilmu, Bandung

Kepner, Charles H dan Tragoe, Benjamin B, (1992), Manajer yang Rasional, Erlangga, Jakarta.

Mc. Leod, Raymond dan Schell, George P, (2008), Sistem Informasi Manejemen, Salemba Empat, Jakarta, pages. 329-330.

Mears, Rebecca \& Sweeney, Kieran, (2000), A preliminary study of the decision-making process within general practice, Family Practice, Volume 17, Issue 5, October 2000, Pages 428-429

Mulyadi, (2003), Teknik Pengambilan Keputusan, Jurnal Efisiensi No. 2, Vol. III, Agustus 2003, FIS UNY, Yogyakarta.

Narbuko, Cholid \& Ahmadi, Abu, (2002), Metodologi Penelitian, Bumi Aksara, Jakarta, p. 1.

Rachman, Eileen, (2017), Sukses Jadi Pemimpin, PT. Gramedia Pustaka Utama, Jakarta, p. 206.

Shihab, M. Quraish, (2000), Tafsir Al-Mishbah Volume 2, PT. Lentera Hati, Jakarta, p. 459.

Siswanto, Agus dkk, (2020), HRD Syariah, PT. Gramedia, Jakarta, Hlm. 108

Sola, Ermi, (2018), Decision Making : Telaah Awal, Jurnal Idaarah, Vol. II, No. 2. Desember 2018, UIN Alauddin Makasar.

Sugiono, (2008) Metode Penelitian Pendidikan: Pendekatan Kuantitatif, Kualitatif dan R\&D, Bandung, Alfabeta, p. 9.

Widyarini, (2012), Manajemen Bisnis dengan Pendekatan Islam, Ekonosia, FE UII, Yogyakarta 
Iwan Fahri Cahyadi, Zulham Fanani

Halaman ini sengaja dikosongkan 